\title{
Inside The Minds and Movement of America's Nonbelievers: Organizational Functions, (Non)Participation, and Attitudes Toward Religion
}

\section{Introduction}

Both Campbell's Toward a Sociology of Irreligion (1971) and Budd's Varieties of Unbelief (1977) described how some members of the secular/freethought movements in late $19^{\text {th }}$ century Britain took a militant approach to religious doctrines, theology, the Bible, and the authority of the church. To these individuals, religion was, at best, nonsense, and, at worst, harmful. Other members preferred a more conciliatory approach characterized by politeness and civility. The latter's goal was obtaining respectability and social acceptance for secularists and atheists. It was their view that the former hostile approach barred those who possessed "advanced religious opinions" from the desired circle of increased social status and thus out of positions of political influence. Indeed, Budd described this division in terms of "militant" and "respectable" wings (Budd 1977, 46, 49, 69), referring to them also as "negative" and "positive" secularism, respectively (also see Rectenwald, this volume).

There are similar divisions between conciliatory and militant views and approaches to secular, humanist, atheist, and freethought (SHAF) movement activism in America today (see Fazzino and Cragun, this volume; Kettell 2013). The noted similarity between this issue today and as described by Campbell and Budd served as the impetus for the study that follows. Has this tension persisted across time, space, and culture? If so, why? Obviously the context covered by Campbell and Budd was quite different from contemporary America, and yet, the term "accommodationist" has come to characterize the conciliatory position for modern American nonbelievers. This term is often applied pejoratively to nonbelievers who are accommodationists by nonbelievers who are not, ${ }^{1}$ whereas

1 The term "accommodationist" was previously and still is used to refer to those who think that science and religion can be accommodated with one another. We point this out to avoid confusion with the term's other, more contemporary usage in referring to accommodation of nonbelievers with the existence of religion.

Ә OpenAccess. () 2017 Joseph Langston, Joseph Hammer, Ryan Cragun \& Mary Ellen Sikes, published by De Gruyter. (cc) BY-NC-ND This work is licensed under the Creative Commons Attribution-NonCommercial-NoDerivatives 4.0 License. https://doi.org/10.1515/9783110458657-011 
those who wish for the elimination of religion have come to be known as "New Atheists"-whether or not such individuals self-consciously subscribe to this label. Campbell (1971, 37-38, 43, 54) referenced these attitudes with the terms "eliminationists" (or "abolitionists"2) and "substitutionists" (or the "replacement” view), although it should be clear that Campbell's substitutionists need not be today's accommodationists, and vice versa. Modern discourse in American SHAF communities does not identify substitutionism and accommodationism as necessarily commensurate, although some contemporary examples of substitutionists in America would include Ethical Culture, some Unitarian Universalist congregations or individuals, and the Sunday Assembly (see chapters by Smith and Frost in this volume). We offer that modern New Atheism in America can still be understood in the same manner described by Campbell in expounding on eliminationism/abolitionism; that is, for our purposes, these terms describe the same attitudinal approach to religion.

Regarding the similarity across place and time, we wondered: what is the "big picture" when it comes to conflicts, schisms, or divisions that might characterize movement participation and SHAF groups in modern America? Nonbelievers in America have been described as a particularly contentious group, prone to fragmentation, and an inability to be organized (although see Smith 2013, 84, who suggests that such problems are becoming a thing of the past; also see Cimino and Smith 2011, 36). Yet, it is not clear how or why this makes them any more disintegrated than other social forms of organization, ecclesiastical or otherwise; in fact, we would observe that instability, inter- and intra-organization contentions, and in-fighting are characteristic of most social movements. Pointedly, Cimino and Smith $(2011,36)$ stated that "publics open to internal antagonism are publics that are active, not fractured." But, in the specific case of nonbelievers and their movement, certain unanswered questions remained. What do nonbelievers who are or are not members of these groups think about the actual or hypothetical goals of these groups? What were these groups doing that might attract or repel greater support? What were groups, leaders, or activists doing that turned people away or polarized either participation in or opinion about the movement? Why didn't nonbelievers who were not members, and never had been, join these groups? When we noticed that the dynamic of eliminationism and accommodationism was present then, in Britain, and now, in the United States, these were the kinds of additional questions that sprang to mind. While

2 "Eliminationism is the belief that religion has proved to be erroneous and harmful and thus needs to be abolished" (345). "Substitutionists...are more concerned with building a movement which can effectively displace religion in all its major functions and thus they favour a less centralised structure capable of meeting the needs of its members" (345). 
some non-empirical literature spoke to these issues, empirical investigations of these questions were nowhere to be found in previous studies of atheism and nonbelief, so we set out in a pioneering effort to address these questions.

\subsection{Previous Research}

A few contemporary studies address the eliminationist-accommodationist dynamic. Kettell (2013, 2014), LeDrew (2012, 2014, 2015), and Cimino and Smith (2007, 2010, 2011) all described contention among individual nonbelievers and their groups since the inception of New Atheism in the first decade of the $21^{\text {st }}$ century. Their work points to differences between New Atheists and those nonbelievers who seek, at the most, cooperation and solidarity with religious groups and individuals on social and political issues of mutual concern, or at the least, polite coexistence. While these two positions are not necessarily mutually exclusive, they can be identified as separate strategies or approaches endorsed by different individuals (Kettell 2013).

Kettell (2014, 381), regarding "the atheist movement" in America as a whole, suggested that it had four aims: reducing the influence of religion in the public sphere; criticizing religious belief and promoting atheism; improving civil rights and the social status of atheists; and community building and group cohesion. Echoing Kettell, but referring to New Atheism specifically, Schulzke (2013) described it as "a loosely defined movement that [...] is not a clearly stated ideology and [...] lacks clear leadership as a social movement. Nevertheless, it is possible to identify points of agreement that many or most New Atheists share, as well as their disagreements with other variants of atheism” (780). New Atheists aggressively and unapologetically challenge both the metaphysical claims made by different religions and religious influence on social life, science, and politics. This approach sets them apart from previous forms of nonbelief, in terms of their high-publicity critiques of both Christianity and Islam, and an unwillingness to compromise or coexist with monotheistic religion (Csaszar 2010; Kettell 2013; McAnulla 2014). Notably, for Schulzke, the New Atheists are differentiated from both pre $20^{\text {th }}$ century atheists and modern atheists inclined toward accommodationism by a greater emphasis on political instead of theological opposition to religion (i.e., the New Atheists advance "a form of political liberalism that coheres to core liberal doctrines" $[2013,779])$ and by their confidence in science, particularly the natural sciences (Cragun 2014). By contrast, then, New Atheism seeks to supersede traditional atheism by attacking religion's incursion into the public sphere; by preventing religion from being an "alternate discourse" along- 
side science; and by elevating atheism as a political cause rather than merely a personal, and thus private, perspective (Schulzke 2013).

Kettell (2013, 66-67) described a more moderate approach to religion within the broader nonbeliever movement. Individuals endorsing this position tend to criticize the New Atheist approach for being an "anti-position" that subordinates "the affirmation of ethical values, humanistic virtues, and democratic principles" (Cimino and Smith 2011, 35). Some members of the SHAF/nonbeliever movement who are not New Atheists could be said to desire a neutral public arena that is equally shared by all (or at least one devoid of any undue bias toward one specific religious tradition). Their approach is characterized more by tolerance, coexistence, and a greater focus on the positive as opposed to negative constitutive attributes of nontheism. Both New Atheists and the more moderate nonbelievers appear to equally share a desire for the separation of church and state, but there is conflict over the style or character of approach that should be used in dealing with religious others, as well as conflict over whether it is more important to improve the image and reputation of nonbelievers (Cimino and Smith 2011; Kettell 2013) versus achieving progress toward a religion-free public sphere. In general, then, New Atheists, as eliminationists, are more likely to think overt hostility is both necessary and justified in the struggle against both the influence and existence of religion, whereas other nonbelievers, as accommodationists, think that a more respectful or less hostile approach is likelier to achieve the desired end of reducing undue religious influence, while leaving religion extant.

Because no research to date has collected data on nonbeliever attitudes regarding movement goals and how best to approach religion, we set out to examine issues that might serve as the arenas of conflict-the "fractures" that exist among American nonbelievers-as opposed to their agreements. Our study was referred to as Atheism Looking In (Langston, Hammer, and Cragun 2014); we were interested in what secularists, humanists, atheists, freethinkers, and nonbelievers in general thought about the broader nonbeliever movement and its aims, and their relation to it. In particular, we were interested in examining attitudes indicative of hostility, or lack thereof, toward religious influence and religious beliefs. As such, we loosely saw our study as a kind of organizational study, but our approach was to examine the movement and its groups through the perceptions of the members who made them up, whether affiliated or not, rather than groups themselves as units of analysis. 


\section{Method: Survey and Sample}

We sent a recruitment email to over 100 American SHAF organizations that were located on the Internet and in various directories on, or maintained by, these groups. The email requested participation in our study and contained a hyperlink to our Qualtrics survey. The first page of the survey contained an informed consent, which specified who was eligible to participate (i.e. those who had resided in the U.S. at least five years or who were U.S. citizens; 18 years of age or older). The survey was operational from January 11th, 2014, to February 9th, 2014. A total of 2,527 respondents started the survey, with 2,006 completing it. After coding and cleaning the data, a total nonrandom sample of 1,939 cases remained, all of which had complete responses to all questions. All data reported in results here are based on these cases, except where noted. Respondents from every U.S. state were represented, from a low of three in Hawaii to a high of 149 from Texas. Thirty-two respondents said they did not live in the United States, but data for these were kept under the assumption that these were U.S. citizens living abroad.

In order to analytically address organizational involvement and identity, we divided our final sample into four categories: members of many SHAF groups ("MGs" for "Many Groups"; $n=581,29.9 \%$ ); members of just one group ("OGs" for "One Group"; $n=356,18.3 \%$ ); respondents who were once members of at least one group but were not members of any groups at the time of the survey ("FMs" for "Former Members"; $n=222,11.4 \%$ ); and respondents who had never been members of such groups ("SNAs" for "Secular Nonaffiliates"; $n=$ $780,40.2 \%)$. This distinction served as a primary means to analyze differences on other questions asked in the study.

First, we asked nonbelievers about their preferred identity labels, and about their preferences for the goals, activities, and functions of nonbeliever groups (some of which reference within-group activities, with others referencing external activities oriented toward religion or the public). Second, we asked MGs, OGs, and FMs why they thought SNAs did not join nonbeliever groups, and we compared their answers side-by-side with the actual reasons given by SNAs. Third, we examined a series of attitudinal questions about approaches to religion, religious believers, and religious beliefs. Fourth, we asked about respondent willingness to include in their communities what may be unpopular social or political opinions, and we also asked how many secular nonaffiliates the respondent personally knew. Fifth, we ran post hoc analyses to examine a variety of gender and identity label differences in opinions and attitudes. Finally, 
we obtained external data from the American Secular Census, which further illuminated our focus and offered corroboration for some of our findings.

\section{Results}

\subsection{What were the age, gender, and racial demographics of our sample?}

Table 1. Age, Gender, and Race by Group Membership

\begin{tabular}{|c|c|c|c|c|c|}
\hline Demographics & $\begin{array}{l}\text { Secular } \\
\text { Nonaffiliates } \\
(n=780)\end{array}$ & $\begin{array}{l}\text { Former } \\
\text { Members } \\
(n=222)\end{array}$ & $\begin{array}{l}\text { One } \\
\text { Group } \\
(n=356)\end{array}$ & $\begin{array}{l}\text { Many } \\
\text { Groups } \\
(n=581)\end{array}$ & $\begin{array}{l}\text { All } \\
(N=1939)\end{array}$ \\
\hline \multicolumn{6}{|l|}{ Age } \\
\hline Mean & 36.02 & 35.82 & 38.98 & 43.62 & 38.82 \\
\hline Median & 33 & 31 & 36 & 43 & 36 \\
\hline Mode & 24 & 26 & 21 & 27 & 21 \\
\hline Range & $18-82$ & $18-86$ & $18-85$ & $18-88$ & $18-88$ \\
\hline \multicolumn{6}{|l|}{ Gender } \\
\hline Male & $62.4 \%$ & $61.5 \%$ & $58.3 \%$ & $61.4 \%$ & $61.9 \%$ \\
\hline Female & $37.6 \%$ & $38.5 \%$ & $41.7 \%$ & $37.9 \%$ & $38.1 \%$ \\
\hline \multicolumn{6}{|l|}{ Race } \\
\hline Nonwhite & $8.8 \%$ & $6.8 \%$ & $5.3 \%$ & $5.5 \%$ & $7.0 \%$ \\
\hline White & $91.2 \%$ & $93.2 \%$ & $94.7 \%$ & $94.5 \%$ & $93.0 \%$ \\
\hline
\end{tabular}

Note: Nine respondents reported "Other" for gender and are excluded from gender reporting in this table.

A one-way ANOVA determined that there was a significant age difference between groups $(F[3,1939]=31.4, p<.001)$. However, because Levene's test for homogeneity of variances revealed that group variances were not equal $(F[3,1939]$ $=14.6, p<.001$ ), we employed a Welch Test, which does not assume equal variances $(F[3,1939]=30.5, p<.001)$. Because this result indicated statistically significant differences between group means on age, post hoc comparisons using the Games-Howell procedure were conducted to determine which pairs of the group membership means differed significantly. MGs $(M=43.62, S D=16.16)$ 
were statistically significantly older than the other three groups $(p<.001)$; OGs $(M=38.98, S D=16.6)$ were statistically significantly older $(p=.01)$ than SNAs $(M$ $=36.02, S D=13.64)$. A Chi-Square test further revealed that there was a statistically significant relationship between age and group membership $\left(\chi^{2}[3,1939]=\right.$ 59.06, $\mathrm{p}<.001, \mathrm{~V}=.17)$. More MGs $(n=355 ; 61.1 \%)$ were part of the older group than the younger group (when splitting age by the median for the total sample). More SNAs (57.4\%) and more FMs (62.6\%) were part of the younger group than the older group.

\subsection{What did these nonbelievers call themselves?}

Table 2. Identity Labels by Group Membership

\begin{tabular}{|c|c|c|c|c|c|}
\hline Label & $\begin{array}{l}\text { Secular } \\
\text { Nonaffiliates } \\
(n=780)\end{array}$ & $\begin{array}{l}\text { Former } \\
\text { Members } \\
(n=222)\end{array}$ & $\begin{array}{l}\text { One } \\
\text { Group } \\
(n=356)\end{array}$ & $\begin{array}{l}\text { Many } \\
\text { Groups } \\
(n=581)\end{array}$ & $\begin{array}{l}\text { All } \\
(N=1939)\end{array}$ \\
\hline Atheist & $78.5 \%$ & $83.3 \%$ & $84.0 \%$ & $90 \%$ & $83.5 \%$ \\
\hline Humanist & $51.4 \%$ & $67.1 \%$ & $56.7 \%$ & $72.8 \%$ & $60.6 \%$ \\
\hline Secular & $51.5 \%$ & $63.1 \%$ & $54.5 \%$ & $68.2 \%$ & $58.4 \%$ \\
\hline Skeptic & $45.6 \%$ & $60.4 \%$ & $45.5 \%$ & $60.2 \%$ & $51.7 \%$ \\
\hline Nonbeliever & $45.4 \%$ & $51.8 \%$ & $48.3 \%$ & $56.1 \%$ & $49.9 \%$ \\
\hline Freethinker & $37.8 \%$ & $40.1 \%$ & $46.1 \%$ & $61.6 \%$ & $46.7 \%$ \\
\hline Rationalist & $31.2 \%$ & $29.7 \%$ & $30.1 \%$ & $40.1 \%$ & $33.5 \%$ \\
\hline Agnostic & $30.3 \%$ & $26.1 \%$ & $23.9 \%$ & $26.7 \%$ & $27.5 \%$ \\
\hline Non-Theist & $19.2 \%$ & $22.5 \%$ & $22.2 \%$ & $34.4 \%$ & $24.7 \%$ \\
\hline Anti-Theist & $18.7 \%$ & $18.9 \%$ & $21.9 \%$ & $32.5 \%$ & $23.5 \%$ \\
\hline $\begin{array}{l}\text { Spiritual But } \\
\text { Not Religious }\end{array}$ & $10.1 \%$ & $9.9 \%$ & $4.8 \%$ & $4.6 \%$ & $7.5 \%$ \\
\hline Other & $4.2 \%$ & $9.5 \%$ & $5.6 \%$ & $7.9 \%$ & $6.2 \%$ \\
\hline
\end{tabular}

Table 2 reports identity labels by group membership level. Selections of labels were mutually inclusive. Even though we used the term "nonbeliever" as an umbrella term, many identity labels can be found in use within SHAF communities. Because these labels, which we assembled from various online sources, were not meant to be exhaustive, we provided an "Other" category in case our respondents did not see their preferred identity labels among the list. It is encouraging 
that only $6.2 \%$ of respondents selected "Other"; even fewer selected none of the 11 labels but only "Other" (eight out of 1,939 respondents, to be exact). Thus, the labels we offered seemed largely adequate to our respondents in order to describe themselves.

\subsection{Which goals, activities, or functions of local, regional, or national groups would these nonbelievers support?}

Table 3. SHAF Group Goals, Activities, and Functions (GAFs) by Group Membership

\begin{tabular}{|c|c|c|c|c|c|c|}
\hline GAF & $\begin{array}{l}\text { Secular } \\
\text { Nonaffiliates } \\
(n=780)\end{array}$ & $\begin{array}{l}\text { Former } \\
\text { Members } \\
(n=222)\end{array}$ & $\begin{array}{l}\text { One } \\
\text { Group } \\
(n=356)\end{array}$ & $\begin{array}{l}\text { Many } \\
\text { Groups } \\
(n=581)\end{array}$ & $\begin{array}{l}\text { All } \\
(\mathrm{N}=1939)\end{array}$ & $\begin{array}{l}\text { Chi Square/ } \\
\text { Cramer's V }\end{array}$ \\
\hline Charity & $73.1 \%^{\mathrm{a}}$ & $77 \%^{a}$ & $75.3 \%^{\mathrm{a}}$ & $86.1 \%^{b}$ & $77.8 \%$ & $\begin{array}{l}X^{2}=34.4 \\
V=.13\end{array}$ \\
\hline S) Activism & $69.4 \%^{\mathrm{a}}$ & $68 \%^{a}$ & $66.6 \%^{\mathrm{a}}$ & $79.3 \%^{b}$ & $71.7 \%$ & $\begin{array}{l}X^{2}=24.9 \\
V=.11\end{array}$ \\
\hline Socialize & $57.8 \%^{\mathrm{a}}$ & $73 \%^{b}$ & $77.5 \%^{b}$ & $84.2 \%^{c}$ & $71.1 \%$ & $\begin{array}{l}X^{2}=122.6 \\
V=.25\end{array}$ \\
\hline Politick & $64.9 \%^{\mathrm{ab}}$ & $71.6 \%^{\mathrm{b}}$ & $61 \%^{a}$ & $84 \%^{c}$ & $70.7 \%$ & $\begin{array}{l}X^{2}=78 \\
V=.20\end{array}$ \\
\hline Discussion & $52.4 \%^{\mathrm{a}}$ & $68 \%^{b}$ & $71.3 \%^{b}$ & $83.8 \%^{\mathrm{c}}$ & $67.1 \%$ & $\begin{array}{l}X^{2}=152.5 \\
V=.28\end{array}$ \\
\hline Litigate & $58.1 \%^{\mathrm{ab}}$ & $64.9 \%^{b}$ & $54.2 \%^{\mathrm{a}}$ & $79 \%^{c}$ & $64.4 \%$ & $\begin{array}{l}\mathrm{X}^{2}=83.7 \\
\mathrm{~V}=.20\end{array}$ \\
\hline Officiate & $41.5 \%^{\mathrm{a}}$ & $44.1 \%^{a}$ & $46.3 \%^{a}$ & $56.8 \%^{\mathrm{b}}$ & $47.3 \%$ & $\begin{array}{l}X^{2}=32.4 \\
V=.12\end{array}$ \\
\hline $\begin{array}{l}\text { Moral } \\
\text { Education }\end{array}$ & $43.7 \%^{a}$ & $41.4 \%^{\mathrm{a}^{*}}$ & $39.3 \%^{\mathrm{a}}$ & $50.4 \% \mathrm{~b}^{\mathrm{b}^{*}}$ & $44.7 \%$ & $\begin{array}{l}X^{2}=13.1 \\
V=.08\end{array}$ \\
\hline Proselytize & $16.9 \%^{\mathrm{a}}$ & $17.6 \%^{a}$ & $19.9 \%^{\mathrm{a}}$ & $32.2 \%^{b}$ & $22.1 \%$ & $\begin{array}{l}X^{2}=50 \\
V=.16\end{array}$ \\
\hline Other & $7.4 \%$ & $9.5 \%$ & $9.3 \%$ & $12.9 \%$ & $9.7 \%$ & $\mathrm{~N} / \mathrm{A}$ \\
\hline
\end{tabular}

Note: Percentages reflect respondents who support each item as a goal, activity, or function of groups at any organizational level. Response options were mutually inclusive. Percentages within rows that do not share superscripts are significantly different at $p<.01$ or lower, with the exception of "Moral Education" ( $p=.02)$ between MGs and FMs, denoted by $\left({ }^{*}\right)$. Because each GAF was collected as its own variable (i. e. selected or not selected), Bonferroni adjustments in pair- 
wise comparisons were not employed in subsequent pairwise comparisons for 2 (selected or not selected) by 2 (group membership x or y) analyses. All omnibus Chi Square and Cramer's V reports for each row are statistically significant, $\mathrm{p}<.001$. For all, $d f=3, \mathrm{~N}=1939$. According to Gravetter and Wallnau (2008), with 3 degrees of freedom, a Cramer's V of .06 or above represents a small effect size; .17 or above represents a medium effect size; and .29 or above represents a large effect size, meaning that Cramer's V for Discussion (.28) and Socialize (.25), as the largest effect sizes for GAFs, approached the threshold of large effect sizes. Discussion = "I think such groups should hold regular meetings for discussing topics related to critical thinking, rationalism, religion, science, philosophy, and other intellectual topics"; Moral Education = "I think such groups should develop and teach programs of moral education and positive values and ethics, or I think such groups should serve as a platform to improve people morally"; Politick = "I think such groups should lobby Congress and lawmakers for secular causes, and, in general, be involved in promoting political views, with the goal of advancing secular views and causes via political processes; such groups should be involved in politics"; Litigate = "I think such groups should litigate and be legal advocates on behalf of secular individuals and causes; such groups should be involved in legal cases"; Socialize = "I think such groups should offer regular social events, recreational outings, and opportunities to socialize and build a sense of community among their members"; Officiate = "I think such groups should provide officials who can conduct life cycle ceremonies such as weddings, funerals, and births"; Proselytize = "I think such groups should use their influence to deliberately convince others to adopt secular or nontheistic views"; Social Justice Activism = "I think such groups should be explicitly involved in social justice efforts to combat racism, sexism, economic inequality, hate crimes, and to support civil rights, equal opportunity, and social equality"; Charity = "I think such groups should be involved in humanitarian activities and charitable contributions".

Compared to the other three groups, MGs over-selected on every goal selection. SNAs only differed from FMs and OGs in SNAs' lower preference for Discussion and Socialize, whereas FMs and OGs only differed on FMs' higher preference for Politick and Litigate. Notably, OGs under-selected compared to SNAs on Social Justice Activism, Politick, Litigate, and Moral Education. 


\subsection{Why didn't secular nonaffiliates join groups? What did affiliated and formerly affiliated nonbelievers think were the reasons that SNAs did not join?}

Table 4. SNA Reasons for Not Joining Groups, Compared to Perceptions of MGs, OGs, and FMs

\begin{tabular}{lll}
\hline Reasons Given & $\begin{array}{l}\text { Secular Affiliates/ } \\
\text { Former Members } \\
(\boldsymbol{n}=1159)\end{array}$ & $\begin{array}{l}\text { Secular } \\
\text { Nonaffiliates } \\
(\boldsymbol{n}=\mathbf{7 8 0})\end{array}$ \\
\hline Low Priority & $55.7 \%$ & $43.6 \%$ \\
\hline Not Local & $54.4 \%$ & $32.6 \%$ \\
\hline Nonbelief Not Big Part Of Self-Identity & $77.5 \%$ & $30.8 \%$ \\
\hline Too Much Like Atheist Church & $49.6 \%$ & $25 \%$ \\
\hline Too Focused On Attacking Religion & $55.2 \%$ & $24.7 \%$ \\
\hline Intellectual Independence & $23.6 \%$ & $17.8 \%$ \\
\hline Other & $13.7 \%$ & $14.7 \%$ \\
\hline Silly, Pointless, Contradictory & $43.1 \%$ & $12.2 \%$ \\
\hline Too Ideological, Dogmatic, Close-Minded & $29.5 \%$ & $11.8 \%$ \\
\hline Stigma & $65 \%$ & $5.9 \%$ \\
\hline Misguided Or Wrong Goals & $22.4 \%$ & $5.1 \%$ \\
\hline No Interest In Discussion Types & $34.6 \%$ & \\
\hline
\end{tabular}

Note: Multiple selections were allowed. Similar questions were asked of both groups; response options listed here were the same for both groups, with the exception of the proper pronoun replacement (e.g. "l” for Secular Nonaffiliates instead of "they" for Secular Affiliates and Former Members). Nonbelief Not Big Part Of Self Identity = "They don't see nonbelief as a primary part of their self-identity; being a nonbeliever is just not a big deal to them". Silly, Pointless, Contradictory = "They think organized forms of nonbelief are silly, pointless, or self-contradicting". Misguided Or Wrong Goals = "They think such groups have misguided or wrong goals". Too Focused On Attacking Religion = "They think nonbelieving groups are too focused on religion, i.e. attacking and criticizing it". Intellectual Independence = "They value their intellectual independence so much that they are not willing to be told by others what to believe or not believe". Too Ideological, Dogmatic, Close-Minded = "They think such groups are too ideological, dogmatic, or closed-minded about their views". Too Much Like Atheist Church = "They think organized nonbelief mimics organized religion too much, i.e. 'atheist church". Stigma = "They don't want to risk the social stigma that might come with being a public nonbeliever". Low Priority = "They would join but they simply have better or more important things to do with their time, i. e. it is low priority". Not Local = "They would join but such groups are not locally or im- 
mediately available to them". No Interest in Discussion Types = "They have no interest in having philosophical, metaphysical, or intellectual conversations about science, religion, etc.”

The guesses of Secular Affiliates and FMs placed the most emphasis on stigma, and on nonbelief not being an important part of SNA self-identity. However, SNAs reported that they mostly did not join because they have more important things to do with their time. Roughly a third of SNAs indicated that they would join if groups were local to them, whereas nearly a third of SNAs said that being a nonbeliever simply wasn't that important to them. Among the "Other" responses, which triggered open-ended short responses in the survey apparatus, 21 respondents indicated "Not enough time"; 14 said that they were "introverted, shy, not social"; another 13 said that they were unaware of available groups nearby, and another 11 indicated that they were "non-joiners". Lastly, 10 respondents indicated that atheists and/or their groups "promoted negative views”.

\subsection{How willing were nonbelievers to endorse nonbeliever groups openly attacking or not attacking religion?}

Table 5. Willingness to Attack or Not Attack Religion by Group Membership

\begin{tabular}{lccccc}
\hline Response & $\begin{array}{l}\text { Secular } \\
\text { Nonaffiliates } \\
(\mathrm{n}=\mathbf{7 8 0})\end{array}$ & $\begin{array}{l}\text { Former } \\
\text { Members } \\
(\mathrm{n}=\mathbf{2 2 2})\end{array}$ & $\begin{array}{l}\text { One } \\
\text { Group } \\
(\mathrm{n}=\mathbf{3 5 6})\end{array}$ & $\begin{array}{l}\text { Many } \\
\text { Groups } \\
(\mathrm{n}=\mathbf{5 8 1})\end{array}$ & $\begin{array}{c}\text { All } \\
(\mathbf{N}=\mathbf{1 9 3 9})\end{array}$ \\
\hline Attack & $4.9 \%$ & $4.5 \%$ & $4.5 \%$ & $6.5 \%$ & $5.2 \%$ \\
\hline Depends & $61.7 \%^{\mathrm{b}}$ & $67.6 \%^{\mathrm{b}}$ & $65.7 \%^{\mathrm{b}}$ & $74.7 \%^{\mathrm{a}}$ & $66.9 \%$ \\
\hline Refrain & $7.3 \%$ & $6.8 \%$ & $4.8 \%$ & $4.3 \%$ & $5.8 \%$ \\
\hline Focus Within & $19.2 \%^{\mathrm{b}}$ & $15.3 \%^{\mathrm{b}}$ & $18 \%^{\mathrm{b}}$ & $9.6 \%^{\mathrm{a}}$ & $15.6 \%$ \\
\hline None Of Above & $6.9 \%$ & $5.9 \%$ & $7 \%$ & $4.8 \%$ & $6.1 \%$ \\
\hline
\end{tabular}

Note: Omnibus $X^{2}(12,1939)=41.3, p<.001, V=.08$. Subsequent $z$-score comparisons for each row, employing Bonferroni corrections $(p=.001)$, revealed that MGs were statistically significantly different from the other three groups on selections for "Depends" and "Focus Within". Attack = "Nonbelieving groups should always or usually openly criticize and attack religion". Refrain = "Nonbelieving groups should always or usually refrain from openly attacking religion". Depends = "What nonbelieving groups should do depends on context and various other factors; sometimes they should openly attack religion, and sometimes they should refrain from openly attacking religion; it depends on various considerations". Focus Within = "Nonbelieving groups 
should not even worry about openly attacking religion, but should instead focus their attentions and efforts within their own groups".

A majority of nonbelievers said that groups should neither refrain from nor always choose to attack or criticize religion and religious beliefs. While small minorities said that groups should always engage in one of these options $(5.2 \%$ Attack vs. 5.8\% Refrain), three times as many said that groups should not worry about attacking religion, but should instead focus their groups' efforts within the group itself.

\subsection{How willing were nonbelievers to seek the eradication of religion, if possible, or to seek common ground with believers and not try to eradicate religion?}

Table 6. Willingness to Eradicate or Accommodate to Religion by Group Membership

\begin{tabular}{llllll}
\hline Response & $\begin{array}{l}\text { Secular } \\
\text { Nonaffiliates } \\
(n=780)\end{array}$ & $\begin{array}{l}\text { Former } \\
\text { Members } \\
(n=222)\end{array}$ & $\begin{array}{l}\text { One } \\
\text { Group } \\
(n=356)\end{array}$ & $\begin{array}{l}\text { Many } \\
\text { Groups } \\
(n=581)\end{array}$ & All \\
\hline Eradicate & $22.6 \%^{\mathrm{a}}$ & $19.8 \%^{\mathrm{a}}$ & $24.4 \%^{\mathrm{a}}$ & $29.1 \%^{\mathrm{b}}$ & $24.5 \%$ \\
\hline Accommodate & $63.3 \%^{\mathrm{a}}$ & $64.9 \%^{\mathrm{a}}$ & $57.6 \%^{\mathrm{a}}$ & $56.1 \%{ }^{\mathrm{b}}$ & $60.3 \%$ \\
\hline Ignore & $3.6 \%$ & $4.5 \%$ & $6.2 \%$ & $4.1 \%$ & $4.3 \%$ \\
\hline Unsure & $10.5 \%$ & $10.8 \%$ & $11.8 \%$ & $10.7 \%$ & $10.8 \%$ \\
\hline
\end{tabular}

Note: While omnibus Chi Square testing was marginally statistically significant different $\left(X^{2}[9\right.$, $1939]=16.5, p=.057, V=.05)$, subsequent $z$-score comparisons for each row, employing Bonferroni corrections $(p=.002)$ revealed that MGs were statistically significantly different from the other three groups on selections for "Eradicate" and "Accommodate", indicated by superscripts across rows. Eradicate $=$ "If possible, religion should be eradicated entirely". Accommodate = "Secularists, nontheists, and atheists should seek accommodation with religious people to achieve common goals; beyond that, they should leave religious people alone and not seek to eradicate religion". Ignore = "Secularists, nontheists, and atheists should neither work with religious people on common causes nor should they seek to eradicate religion in its various forms".

A majority of nonbelievers said that nonbelievers should not only work with religious people to accomplish common goals, such as the separation of church and state, but that no attempt should be made to eradicate religion. A quarter of respondents opted for the elimination option, whereas very few said that nonbelievers should pursue neither course of action. While we cannot say anything definitive about the relatively high number of "Unsure" responses on this ques- 
tion, this could be indicative of ambivalence about how to approach religious people and religious beliefs. It could also be indicative of an attitude which suggests that nonbelievers should work with believers to achieve common goals while simultaneously seeking to eradicate religion, an opinion offered by at least one respondent in post-study feedback.

\subsection{How willing were nonbelievers to mock or ridicule religious beliefs, or to refrain from doing so?}

Table 7. Willingness to Use or Not Use Mockery/Ridicule of Religion by Group Membership

\begin{tabular}{|c|c|c|c|c|c|}
\hline Response & $\begin{array}{l}\text { Secular } \\
\text { Nonaffiliates } \\
(n=780)\end{array}$ & $\begin{array}{l}\text { Former } \\
\text { Members } \\
(n=222)\end{array}$ & $\begin{array}{l}\text { One } \\
\text { Group } \\
(n=356)\end{array}$ & $\begin{array}{l}\text { Many } \\
\text { Groups } \\
(n=581)\end{array}$ & $\begin{array}{l}\text { All } \\
(\mathrm{N}=1939)\end{array}$ \\
\hline Avoid & $37.2 \%^{\mathrm{a}}$ & $31.5 \%^{\mathrm{a}}$ & $34.6 \%^{\mathrm{a}}$ & $22 \%^{b}$ & $31.5 \%$ \\
\hline Depends & $54.9 \%^{\mathrm{a}}$ & $58.6 \%^{\mathrm{a}}$ & $57.9 \%^{a}$ & $69 \%^{b}$ & $60.1 \%$ \\
\hline Don't Avoid & $6 \%$ & $6.3 \%$ & $5.9 \%$ & $7.7 \%$ & $6.5 \%$ \\
\hline Unsure & $1.9 \%$ & $3.6 \%$ & $1.7 \%$ & $1.2 \%$ & $1.9 \%$ \\
\hline
\end{tabular}

Note: Omnibus $X^{2}(9,1939)=44.1, p<.001, V=.08$. Subsequent $z$-score comparisons for each row, employing Bonferroni corrections $(p=.002)$ revealed that MGs were statistically significantly different from the other three groups on "Avoid" and "Depends", indicated by superscripts across rows. Avoid = "Mockery and ridicule of religious people and religious beliefs should be avoided; they are counterproductive or make nonbelievers look bad”. Don't Avoid = "Mockery and ridicule of religious people and religious beliefs should be encouraged or used; it is the treatment that religious beliefs deserve, and to avoid using them is to give religious people and religious beliefs a free pass that they don't deserve". Depends = "Some degree of mockery and ridicule are acceptable and/or recommendable, but it just depends on various different things".

A majority said that whether mockery and ridicule should be applied to religious people and religious beliefs simply depends on various considerations. A relatively large minority of respondents said that mockery and ridicule should be avoided because they are counter-productive or make nonbelievers look bad, although fewer MGs than any of the other groups selected this option. 


\subsection{How willing or unwilling were nonbelievers to include or exclude unpopular social or political opinions from their communities or the movement in general?}

Table 8. Willingness to Accept or Not Accept Unpopular Social and Political Opinions in Secular/Atheist Communities by Group Membership

\begin{tabular}{llllll}
\hline Response & $\begin{array}{l}\text { Secular } \\
\text { Nonaffiliates } \\
(n=780)\end{array}$ & $\begin{array}{l}\text { Former } \\
\text { Members } \\
(n=222)\end{array}$ & $\begin{array}{l}\text { One } \\
\text { Group } \\
(n=356)\end{array}$ & $\begin{array}{l}\text { Many } \\
\text { Groups } \\
(n=581)\end{array}$ & All \\
\hline Incompatible & $17.8 \%^{\mathrm{a}}$ & $14.0 \%^{\mathrm{a}}$ & $20.8 \%^{\mathrm{a}}$ & $24.3 \%^{\mathrm{b}}$ & $19.9 \%$ \\
\hline Compatible & $71.7 \%$ & $74.3 \%$ & $65.7 \%$ & $66.3 \%$ & $69.3 \%$ \\
\hline Not Sure & $10.5 \%$ & $11.7 \%$ & $13.5 \%$ & $9.5 \%$ & $10.9 \%$ \\
\hline
\end{tabular}

Note: Omnibus $\mathrm{X}^{2}(6,1939)=17.7, p=.007, \mathrm{~V}=.06$. Incompatible and Compatible options refer to whether the respondent thought that unpopular social or political opinions were incompatible or compatible with a secular view of the world, and thus acceptable or unacceptable views to be held in SHAF communities. Subsequent $z$-score comparisons for each row, employing Bonferroni corrections $(p=.002)$ revealed that MGs are statistically significantly different $(p<.05)$ from the other three groups on "Incompatible", indicated by superscripts across rows.

The nonbeliever movement has sustained problems with diversity issues (Hassall and Bushfield 2014; Kettell 2013, 67; Miller 2013; Schnabel et al. 2016), including racism, sexism, and social justice issues. On this question, we were not able to specify which sorts of social or political opinions we intended, without leading respondents. If we had been very specific, these answers may very well have changed, but, the question as we asked it was meant to be taken by the respondent as meaning whatever they imagined regarding "social" and "political" opinions. This may account for the relatively high amount of "Not Sure" responses. At any rate, the majority attitude of nonbelievers here was characterized by inclusion rather than exclusion. 


\subsection{What did nonbelievers think about the compatibility, or lack thereof, between science and religion?}

Table 9. Compatibility of Science and Religion by Group Membership

\begin{tabular}{|c|c|c|c|c|c|}
\hline Response & $\begin{array}{l}\text { Secular } \\
\text { Nonaffiliates } \\
(n=780)\end{array}$ & $\begin{array}{l}\text { Former } \\
\text { Members } \\
(n=222)\end{array}$ & $\begin{array}{l}\text { One } \\
\text { Group } \\
(n=356)\end{array}$ & $\begin{array}{l}\text { Many } \\
\text { Groups } \\
(n=581)\end{array}$ & $\begin{array}{l}\text { All } \\
(N=1939)\end{array}$ \\
\hline Incompatible & $48.7 \%^{\mathrm{a}}$ & $49.1 \%^{\mathrm{a}}$ & $56.7 \%{ }^{a, b}$ & $60.1 \%^{b}$ & $53.6 \%$ \\
\hline Pretend Compatible & $25.5 \%$ & $25.2 \%$ & $26.1 \%$ & $25.5 \%$ & $25.6 \%$ \\
\hline Compatible & $25.8 \%^{\mathrm{a}}$ & $25.7 \%$ a, b & $17.1 \%, b, c$ & $14.5 \%^{c}$ & $20.8 \%$ \\
\hline
\end{tabular}

Note: Omnibus $X^{2}(6,1939)=34.8, p<.001, V=.09$. Subsequent $z$-score comparisons for each row, employing Bonferroni corrections $(p=.002)$, revealed that MGs differed from FMs and SNAs but not OGs on "Incompatible". MGs differed from FMs and SNAs but not OGs on "Compatible", whereas OGs differed only from SNAs on this option. Incompatible = "Science and religion are obviously incompatible; faith is irrational, and endorsing the unity of science and religion only enables delusion". Pretend Compatible = "Science and religion are not truly compatible but we should pretend that this is the case so as not to lose public support for science; it is valuable for nonbelievers to work alongside religious believers to pursue shared goals, and an individual's religious belief is irrelevant unless it leads them to distort or misrepresent science". Compatible = "Science and religion may answer different questions but they are compatible in certain ways; failing to see this is either unimaginative or intolerant".

Extending the accommodationist versus eliminationist argument to discussions of science and religion, we tried to formulate questions that would reflect these varying approaches. Attitudes about science and religion among members of the SHAF movement have ranged from compatible (Gould 1999) to incompatible (Stenger 2009). The Pretend Compatible response was our attempt to provide an option for those who, while not seeing science and religion as compatible, would not choose to make an issue out of this disjunction as long as it did not threaten the integrity of the scientific process. Given these selections alongside Incompatible responses, which came from a majority of each group membership category, most nonbelievers do not think science and religion are compatible, though the gap between MGs and SNAs on Compatible is particularly salient. 


\section{Additional Analyses: Gender}

The statistically significant demographic differences that emerged across our questions primarily centered upon gender rather than age or race, thus we present the gender differences of interest only.

\subsection{What were the gender differences, if any, for GAF selections?}

Table 10. Gender Differences on Goals, Activities, and Functions (GAF) Selections

\begin{tabular}{llll}
\hline GAF & $\begin{array}{l}\text { Male } \\
(n=1185)\end{array}$ & $\begin{array}{l}\text { Female } \\
(n=745)\end{array}$ & $\begin{array}{l}\text { Chi Square/ } \\
\text { Cramer's V }\end{array}$ \\
\hline Proselytize & $29.1 \%$ & $10.7 \%$ & $\mathrm{X}^{2}=90, \mathrm{~V}=.21$ \\
\hline Litigate & $69.7 \%$ & $56 \%$ & $\mathrm{X}^{2}=37.6, \mathrm{~V}=.14$ \\
\hline Politick & $73.3 \%$ & $66.4 \%$ & $\mathrm{X}^{2}=10.4, \mathrm{~V}=.07$ \\
\hline Officiate & $44.9 \%$ & $51.3 \%$ & $\mathrm{X}^{2}=7.4, \mathrm{~V}=.06$ \\
\hline
\end{tabular}

Note: For all, $d f=1, p<.001$, except Officiate, $p=.006$. GAFs were only included here if they reached statistical significance with gender.

Females had a lower preference for Proselytize, whereas more minor gender differences emerged in the lower female selections of Litigate, Politick, and Officiate. 


\subsection{What were the gender differences, if any, on opinion and attitudinal questions?}

Table 11. Gender Differences on Questions 3.5, 3.6, 3.8, and 3.10

\begin{tabular}{|c|c|c|c|}
\hline Attack or Not Attack & $\begin{array}{l}\text { Male } \\
(n=1185)\end{array}$ & $\begin{array}{l}\text { Female } \\
(n=745)\end{array}$ & $\begin{array}{l}\text { Chi Square/ } \\
\text { Cramer's V }\end{array}$ \\
\hline Attack $^{\mathrm{a}}$ & $7.3 \%$ & $1.7 \%$ & \multirow{5}{*}{$\begin{array}{l}X^{2}(4,1930)=81.5, p<.001 \\
V=.20\end{array}$} \\
\hline Depends $^{\mathrm{a}}$ & $71.2 \%$ & $60.4 \%$ & \\
\hline Refrain $^{a}$ & $4.2 \%$ & $8.6 \%$ & \\
\hline Focus Within ${ }^{\mathrm{a}}$ & $12 \%$ & $21.5 \%$ & \\
\hline None of the Above ${ }^{a}$ & $5.2 \%$ & $7.8 \%$ & \\
\hline Eradicate or Accommodate & $\begin{array}{r}\text { Male } \\
(n=1185)\end{array}$ & $\begin{array}{l}\text { Female } \\
(n=745)\end{array}$ & $\begin{array}{l}\text { Chi Square/ } \\
\text { Cramer's V }\end{array}$ \\
\hline Eradicate $^{\mathrm{a}}$ & $30.5 \%$ & $15 \%$ & \multirow{4}{*}{$\begin{array}{l}X^{2}(3,1930)=64.9, p<.001 \\
V=.18\end{array}$} \\
\hline Accommodate $^{a}$ & $54 \%$ & $70.3 \%$ & \\
\hline Ignore & $4.4 \%$ & $4.2 \%$ & \\
\hline Unsure/Undecided & $11.1 \%$ & $10.5 \%$ & \\
\hline Use of Mockery and Ridicule & $\begin{array}{r}\text { Male } \\
(n=1185)\end{array}$ & $\begin{array}{l}\text { Female } \\
(n=745)\end{array}$ & $\begin{array}{l}\text { Chi Square/ } \\
\text { Cramer's V }\end{array}$ \\
\hline Avoid $^{\mathrm{a}}$ & $24.6 \%$ & $42.7 \%$ & \multirow{4}{*}{$\begin{array}{l}X^{2}(3,1930)=89.1, p<.001 \\
V=.21\end{array}$} \\
\hline Depends $^{\mathrm{a}}$ & $65.1 \%$ & $52.2 \%$ & \\
\hline Don’t Avoid ${ }^{a}$ & $8.9 \%$ & $2.7 \%$ & \\
\hline Unsure & $1.5 \%$ & $2.4 \%$ & \\
\hline Science and Religion & $\begin{array}{l}\text { Male } \\
(n=1185)\end{array}$ & $\begin{array}{l}\text { Female } \\
(n=745)\end{array}$ & $\begin{array}{l}\text { Chi Square/ } \\
\text { Cramer's V }\end{array}$ \\
\hline Incompatible ${ }^{a}$ & $59.3 \%$ & $44.4 \%$ & \multirow{3}{*}{$\begin{array}{l}X^{2}(2,1930)=58.2, p<.001 \\
V=.17\end{array}$} \\
\hline Pretend Compatible & $25 \%$ & $26.6 \%$ & \\
\hline Compatible $^{\mathrm{a}}$ & $15.7 \%$ & $29 \%$ & \\
\hline
\end{tabular}

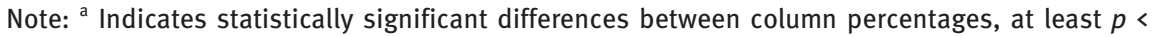
.05 .

Although majorities chose to circumstantially criticize or ridicule/mock religion, wherever respondents had the opportunity to decide between eliminationist and accommodationist attitudes, females exhibited the latter more so than males. The fact that the nonbeliever movement is majority male may especially contribute to public perceptions (or the actuality) that it is a hostile or militant movement (cf. also Silver et al., 2014, on descriptions of anti-theism and views of "types" of nonbelievers of one another). 


\section{Identity Labels: Evidence That They Matter}

We endeavored to provide additional analysis for "atheist", "secular", and "humanist" identity labels because some literature suggests potential "approach" differences between secular humanists and atheists (e. g. Kettell, 2013, 2014; Cimino and Smith, 2007, 2011; Smith and Cimino, 2012). Only 75 respondents (3\%) selected, at least, both "secular" and "humanist" but not "atheist". On the other hand, 387 respondents (19.9\%) selected, at least, "atheist" but neither "secular" nor "humanist". A majority of 822 respondents (42.3\%) selected all three of these labels, whereas 142 respondents (9.9\%) selected, at the least, none of these three labels. This left 513 ALI respondents (26.4\%) who did not fall into any of these four reconstituted categories. What were the differences, if any, between these four categories?

\subsection{How did these identity labels compare on GAF selections?}

Table 12. Identity Label Differences on Goals, Activities, and Functions (GAF) Selections

\begin{tabular}{lcccccl}
\hline GAF & $\begin{array}{l}\text { SH Not } \\
\text { Atheists } \\
(n=75)\end{array}$ & $\begin{array}{l}\text { Atheists } \\
\text { Not SH } \\
(n=387)\end{array}$ & $\begin{array}{l}\text { All } \\
\text { Three } \\
(n=822)\end{array}$ & $\begin{array}{l}\text { None of } \\
\text { the Three } \\
(n=142)\end{array}$ & $\begin{array}{l}\text { All } \\
(\mathbf{N}=1426)\end{array}$ & $\begin{array}{l}\text { Chi Square/ } \\
\text { Cramer's V }\end{array}$ \\
\hline Politick & $64 \%^{\mathrm{a}}$ & $65 \%^{\mathrm{a}}$ & $80 \%^{\mathrm{b}}$ & $48.6 \%^{\mathrm{c}}$ & $72.5 \%$ & $\mathrm{X}^{2}=80, \mathrm{~V}=.23$ \\
\hline Discussion & $74.7 \%^{\mathrm{a}}$ & $56.6 \%^{\mathrm{b}}$ & $77.1 \%^{\mathrm{a}}$ & $50 \%^{\mathrm{b}}$ & $68.7 \%$ & $\mathrm{X}^{2}=77.9, \mathrm{~V}=.23$ \\
\hline Litigate & $58.7 \%^{\mathrm{a}}$ & $59.2 \%^{\mathrm{a}}$ & $74.8 \%^{\mathrm{b}}$ & $41.5 \%^{\mathrm{c}}$ & $66.4 \%$ & $\mathrm{X}^{2}=76.4, \mathrm{~V}=.23$ \\
\hline Charity & $82.7 \%^{\mathrm{a}}$ & $68.5 \%^{\mathrm{b}}$ & $86.6 \%^{\mathrm{a}}$ & $64.1 \%^{\mathrm{b}}$ & $79.2 \%$ & $\mathrm{X}^{2}=74.8, \mathrm{~V}=.23$ \\
\hline SJ Activism & $86.7 \%^{\mathrm{a}}$ & $64.3 \%^{\mathrm{b}}$ & $79.8 \%^{\mathrm{a}}$ & $52.8 \%^{\mathrm{b}}$ & $73.3 \%$ & $\mathrm{X}^{2}=70.9, \mathrm{~V}=.22$ \\
\hline Socialize & $66.7 \%^{\mathrm{a}}$ & $61.2 \%^{\mathrm{a}}$ & $79.2 \%^{\mathrm{b}}$ & $55.6 \%^{\mathrm{a}}$ & $71.3 \%$ & $\mathrm{X}^{2}=62, \mathrm{~V}=.21$ \\
\hline Officiate & $54.7 \%^{\mathrm{a}}$ & $34.4 \%^{\mathrm{b}}$ & $56.3 \%^{\mathrm{a}}$ & $36.6 \%^{\mathrm{b}}$ & $48.3 \%$ & $\mathrm{X}^{2}=60.2, \mathrm{~V}=.20$ \\
\hline Moral & $46.7 \%^{\mathrm{ac}}$ & $33.9 \%^{\mathrm{b}}$ & $51.5 \%^{\mathrm{a}}$ & $41.5 \%^{\mathrm{bc}}$ & $45.4 \%$ & $\mathrm{X}^{2}=33.9, \mathrm{~V}=.15$ \\
Education & & & & & & \\
\hline Proselytize & $10.7 \%^{\mathrm{a}}$ & $19.4 \%^{\mathrm{a}}$ & $27.6 \%^{\mathrm{b}}$ & $12.7 \%^{\mathrm{a}}$ & $23 \%$ & $\mathrm{X}^{2}=27.7, \mathrm{~V}=.14$ \\
\hline
\end{tabular}

Note: For all, $d f=3, p<.001$. Percentages in rows that do not share the same superscript are statistically significantly different, at least $p<.05$. "Secular Humanists" was constructed by combining those who chose, at least, both "Secular" and "Humanist" from identity labels, de- 
spite the fact that not everyone who selected one selected the other; see Table 2. From ALI, at least 1,132 respondents chose, at least, "Secular" and 1,175 chose, at least, "Humanist".

Those who selected "All Three" identity labels were different on every goal selection from both "Atheists Not Secular Humanists" and "None of the Three". "Secular Humanists Not Atheists", when compared to "Atheists Not Secular Humanists", showed higher selections on each goal for which they were statistically significantly different. In this regard, "Atheists Not Secular Humanists" were more similar to "None of the Three" than were "Secular Humanists Not Atheists", whereas this latter group was more similar to "All Three". Those selecting "All Three" labels out-selected the other three groups on all goals, except for Social Justice Activism, which was most selected by "Secular Humanists Not Atheists". Thus, secular humanists who did not also call themselves atheists were more similar to those who identified with all three labels, whereas those who only called themselves atheists, and not secular humanists, were more similar to those who chose none of these labels, though the differences between all four groups are also apparent (cf. Cotter, 2015).

\section{Additional Data: The American Secular Census}

In the course of carrying out our study, we became aware of another data source which shed additional light on our topic: the American Secular Census (ASC). Launched on November 7, 2011, the ASC describes itself as an independent national registry of demographic and viewpoint data recorded on secular Americans. Census registrants are U.S. citizens or permanent residents over 18 years of age who are skeptical of supernatural claims, including those generally associated with religion. Each registrant maintains an ASC website account used to complete 13 Census forms which collect personal and household information, a secular profile, a religious profile, political activism and voting patterns, philanthropy habits, parenting information, military service, experiences with discrimination, public policy and social views, and opinions about secular advocacy.

For the purpose of making comparisons to our own data, we acquired data from Personal and Secular Profiles in the ASC online database on November $14^{\text {th }}$, 2015. At that time, the sample size for registrants who had completed both forms was 1,340 respondents. Table 13 shows a comparison of age, gender, and race between ALI and ASC samples. Notably, the ASC respondents were older than ALI respondents. Outside of this, although we cannot make statistical comparisons, both sets of data seem surprisingly similar, though both are composed of nonrandom, self-selected samples. 


\subsection{What were the demographic similarities or differences between ALI and ASC?}

Table 13. Age, Gender, and Race Comparison between ALI and ASC

\begin{tabular}{|c|c|c|c|}
\hline $\begin{array}{l}\text { Atheism Looking In } \\
(\mathrm{N}=1939)\end{array}$ & & $\begin{array}{l}\text { American Secular Census } \\
(\mathrm{N}=1340)\end{array}$ & \\
\hline & & & \\
\hline Mean & 38.8 & Mean & 42.3 \\
\hline Median & 36 & Median & 40 \\
\hline Mode & 21 & Mode & 31 \\
\hline \multirow[t]{2}{*}{ Range } & $18-88$ & Range & $19-86$ \\
\hline & & & \\
\hline Male & $1185(61.1 \%)$ & Male & 778 (58.1\%) \\
\hline Female & 745 (38.4\%) & Female & $539(40.2 \%)$ \\
\hline \multirow[t]{2}{*}{ Other } & $9(0.05 \%)$ & Other & $23(1.7 \%)$ \\
\hline & & & \\
\hline Nonwhite & $135(7 \%)$ & Nonwhite & $123(9.1 \%)$ \\
\hline White & 1804 (93\%) & White & $1217(90.8 \%)$ \\
\hline
\end{tabular}




\subsection{How active in the nonbeliever movement were ASC respondents?}

Table 14. ASC Respondent Level of Involvement in the Nonbeliever Movement

\begin{tabular}{lr}
\hline Level of Involvement & Frequency (N = 1340) \\
\hline I'm aware of organizations and events but have not participated & $40.7 \%$ \\
\hline I'm slightly active in the movement & $27.9 \%$ \\
\hline I'm pretty active in the movement & $8.8 \%$ \\
\hline None; l'm vaguely aware it exists but haven't explored further & $6.1 \%$ \\
\hline I'm an insider (e.g. leader, employee, major donor) & $5.5 \%$ \\
\hline None; this is the first l've heard of it & $5.2 \%$ \\
\hline I'm a former participant who is currently inactive & $5 \%$ \\
\hline Something not listed here & $0.8 \%$ \\
\hline
\end{tabular}

SNAs comprised $40.2 \%$ of the ALI sample. In the ASC sample, those who are comparable make up 52\%, if adding the first, fourth, and sixth categories from Table 14. If respondents indicated that they were not active in the atheist/secular movement (in this case, however, using only Options 1 and 7 from Table 14), this triggered a conditional question in the ASC questionnaire which asked about their reasons for not being involved. 


\subsection{What reasons did inactive ASC respondents give for lack of participation?}

Table 15. ASC Inactive Respondent Reasons for Lack of Nonbeliever Movement Participation

\begin{tabular}{lr}
\hline Reason & Frequency $(\boldsymbol{n}=\mathbf{6 1 3})$ \\
\hline Insufficient time & $57.9 \%$ \\
\hline Events inconvenient & $37.4 \%$ \\
\hline Insufficient money & $36.4 \%$ \\
\hline Not a joiner & $31 \%$ \\
\hline Some other reason & $16.5 \%$ \\
\hline Events uninteresting to me & $10.8 \%$ \\
\hline Not really sure & $10.4 \%$ \\
\hline General disinterest & $9.6 \%$ \\
\hline Fear of damaging my relationships & $8.8 \%$ \\
\hline Lack of childcare & $8 \%$ \\
\hline Bad experience with group, person, or event & $7.8 \%$ \\
\hline Don't see relevance to my life & $6 \%$ \\
\hline Not open about my secularism & $5.2 \%$ \\
\hline Health issues & $4.7 \%$ \\
\hline Publications uninteresting to me & $2.3 \%$ \\
\hline
\end{tabular}

Even though ALI provided an "Other" category so that respondents could list reasons that were not part of the formal listing, $36 \%$ of inactive ASC respondents said that "Insufficient Money" was a reason for lack of participation; this did not emerge at all in our study. Because selections for "Events Inconvenient" and "Insufficient Money" were very close, we further determined that 112 respondents (18.2\%) selected both options, meaning that for a majority, these were distinct selections. The top reason for inactivity, "Insufficient Time", would support our own finding that respondents did not prioritize participation. This raises the question of whether these respondents would join or participate more often if they did have the time. Also, though lack of time is comparable to participation being a low priority, neither of these compares to nonbelief not being a salient component of self-identity (see Stryker 2000). Nonbelief could 
be a primary part of self-identity even in the event of insufficient time or if one has higher-priority life obligations (e.g. family, work, practical projects, hobbies, friends, etc.). Roughly a third of respondents from ALI said that they would join groups if they were local; this compares to $37 \%$ of non-active nonbelievers from ASC saying that events are "inconvenient", though inconvenience could also refer to schedule conflict, not physical proximity or lack of local groups. This point also dovetails with lack of time as a top reason. Lastly, 31\% of ASC nonaffiliates said they were not joiners, which comports with the qualitative responses we received from 14 ALI respondents (see Table 4), indicating that they were introverted, shy, not social, or not interested in socializing.

\subsection{What did ASC respondents find beneficial about their involvement in nonbeliever groups?}

Table 16. Benefits of Participation Experienced by ASC Respondents

\begin{tabular}{lr}
\hline Benefits & Frequency $(n=641)$ \\
\hline Friendships and community & $74.9 \%$ \\
\hline Personal development & $47.3 \%$ \\
\hline Social or cultural acceptance & $43.2 \%$ \\
\hline Educational resources & $32.8 \%$ \\
\hline Service opportunities & $25.4 \%$ \\
\hline Moral guidance & $15.3 \%$ \\
\hline Political influence & $15.3 \%$ \\
\hline Support with family issues & $11.2 \%$ \\
\hline No benefits at all & $8.1 \%$ \\
\hline Support with other problems & $6.6 \%$ \\
\hline Something not listed here & $6.2 \%$ \\
\hline Career opportunities & $4.8 \%$ \\
\hline Youth programs & $3.3 \%$ \\
\hline Support with substance abuse & $0.5 \%$ \\
\hline
\end{tabular}

An alternate strategy to our own would have been to ask secular affiliates about the advantages of participation in the movement and membership in its groups. 
As Table 16 shows, the most frequently derived benefits were friendships and community; personal development (e.g. leadership, confidence); and social or cultural acceptance, a factor that we would suggest probably relates to stigma against nonbelievers in America (see Table 4).

\subsection{What did ASC respondents find disadvantageous about their involvement in nonbeliever groups?}

Table 17. Disadvantages of Participation Experienced by ASC

Respondents

\begin{tabular}{lr}
\hline Disadvantages & Frequency $(n=641)$ \\
\hline No disadvantages at all & $51.3 \%$ \\
\hline Problems with family members & $24.6 \%$ \\
\hline Problems with friends & $15 \%$ \\
\hline Problems within the organization itself & $12.8 \%$ \\
\hline Problems in the workplace & $9.2 \%$ \\
\hline Problems in my community & $7.3 \%$ \\
\hline Conflict with mission or values & $7 \%$ \\
\hline Something not listed here & $6.2 \%$ \\
\hline
\end{tabular}

Yet another approach alternate to ours would have been to ask about disadvantages that came with movement and group participation. In Table 17, a majority reported no disadvantages due to their participation, whereas, consistent with Cragun et al. (2012), the most likely disadvantages occurred for social relationships with family members or friends. With regard to internal conflict, $12 \%$ said they had problems within their own groups, while another $7 \%$ said they had conflict with the nonbeliever movement mission or values.

\section{Conclusion}

Some nonbelievers don't have time to join groups but would if they in fact did have time, and if these groups and related events were readily available and convenient. For these nonbelievers, nonbelief is a part of their identity; for others, nonbelief is not a part of their identity, and they would not join such groups 
even if they had the time or if such groups were available. Though using a small sample, Cimino and Smith (2011) found that an appreciable number of their respondents engaged in activism and participation exclusively online. A separate but relevant issue concerns historical anti-authoritarianism and the tendency toward a decentralized organization of humanist, atheist, and freethought groups (Budd 1977). The Internet provides the opportunity, for those for whom nonbelief is important, to engage in movement participation and activism; this may comport well with a preference for individual, or non-institutional activism carried out on the individual's own terms. On this basis, many SNAs likely eschew formal organizational participation in favor of private, individual participation. This is similar to Cimino and Smith's $(2011,32)$ "cultural secularists", who "[try] to discredit religious belief and advocate for change on more personal and individual terms, outside the channels created for this purpose by the dominant secular organizations."

Our gender differences in particular proved interesting. The lesser hostility of women betokens consequences for a movement that is male-dominated in both its membership and its leadership; it stands to reason that a female-led movement might result in noticeable differences in strategies, and thus also outcomes. It is possible that such a movement might more readily achieve social acceptance in the American public at large, or at least diminished stigma-although this in turn depends on what one thinks about the efficacy of an accommodationist strategy over an eliminationist strategy (see Cragun and Fazzino, this volume, concerning the organizational leadership of Madalyn Murray O'Hair). Certainly, females in our data demonstrate a willingness to engage in mockery/ridicule and criticism of religion and religious beliefs, regardless of whether they selected "elimination" or "accommodation". To the extent that female leadership increases, this may result in a more gender-balanced membership. Although this seems obvious, such change in leadership may also have the effect of increasing the number of women in the movement by virtue of the fact that "hostile" attitudes turn them away. Noticeably, 33\% of our SNA female respondents said that one reason they didn't join groups was because of how focused such groups were on attacking or criticizing religion (compared to $19 \%$ of male respondents).

We cannot suggest that gender differences in attitudes toward hostility, mockery, and criticism of religion are a strong ground of contention that exists in and between groups that make up the nonbeliever or secular movement (pointedly, most of our males also fall into the more accommodating half of this attitudinal divide). Some data indicate that the gender ratio among nonbelievers has shifted in favor of a growing number of women (cf. Hassall and Bushfield 2014; cf. also Barna Group, 2015). Nevertheless, it is possible that part of this increasing diversity in membership is a result of strategy differences 
where women have come to gain greater and more positions of leadership. If not actual, the effect is at least feasible.

The questions we asked and the data we analyzed were part of our effort to ultimately understand differences between nonbeliever ideas, preferences, and attitudes across a variety of affiliative statuses. Despite a nonrandom sample, the greatest value provided by our study comes from descriptive insights that can be examined when and if a viable random sample becomes available. For example, perhaps nonbelieving men and women in the larger population do not truly differ regarding eliminationist and otherwise hostile attitudes toward religion, but, as we found the opposite here, future research can investigate a random sample to see if this relationship would hold. The same notion applies to any descriptive insights generated from this study. Future studies should take note of the fact that some nonbelievers could be described as the opposite of "MG/All Three" individuals. In other words, we can identify this category of nonbeliever as someone for whom nonbelief is highly inconsequential, a facet of their lives that likely does not shape or influence behaviors and activities (these would be "apatheists” per Shook's chapter in this volume). It seems likely that this group could only be reached through a nationally representative random survey (e.g. GSS, ARIS, etc.), although at present such nationally representative datasets do not contain data concerning secular and atheist organizations. It would be interesting to see if and/or how this category differed from our four groups. Future studies might further benefit from determining why it is that former members of groups are, in fact, former members, that is, the circumstances or reasons for their disaffiliation. We speculate that such reasons would largely resonate with the more pragmatic, as opposed to ideological, concerns that were expressed here.

One assumption we employed was that dividing respondents into the four group categories would produce meaningful analyses. While this is obvious, there are finer group membership conceptualizations that might have been used to greater analytical effect, such as those found in the ASC (see Table 14). In the sociology of religion, categories such as belief, belonging, identification, behavior, and salience are employed in the quantitative analysis of religion; we would suggest that similar categories, if considered dynamically (and dimensionally?) rather than statically, might prove useful in analyzing nonbelievers and distinctions among them (see Cotter 2015; Silver et al. 2014). Because we sought to gauge "approach" attitudes toward religion, a better method for measurement in the future might be to develop a survey instrument with standardized responses, measured at least ordinally so that other, more sophisticated assessments could be made. Lastly, Mastiaux's chapter in this volume is a fine example of how organization members and their "participation motives" may be charac- 
terized; as a qualitative study, it is a welcome complement to our own quantitative approach.

It is worth bearing in mind that the nonbeliever movement did, in fact, exist prior to the year 2000, yet it has more vitality and visibility today than before. What ultimately becomes of it will depend, in part, on the vitality and condition of American religion. Despite the fact that Christianity in America has been forecasted to decline (Hackett et al. 2015; Stinespring and Cragun 2015), it seems unlikely that a minority of American nonbelievers would wish to back off from a chance to either effectively rid their country of religion, or at least secure a victory for neutrality in the public and political spheres. If American Christianity does decline as predicted (as other organizational participation has; Putnam, 2001), then this might attenuate types and magnitudes of divisions between various nonbelievers, especially to the extent that such decline might bring about reduced religious influence in the political sphere, or greater social acceptability of nonbelievers. It could also have the effect of shifting SHAF strategies and approaches to eliminationist or accommodationist sides, such that one approach becomes more dominant than the other. Until then, as Kettell $(2013,2014)$ and Cimino and Smith (2011) have noted, both eliminationist and accommodationist approaches fulfill niches that match the desires of respective movement members. Kettell $(2014,388)$ offers that this may be to the advantage of such a movement:

The absence of a consistent or uniform approach furnishes the movement with a high degree of flexibility and dynamism, enabling the formation of loose and adaptive alliances in response to specific issues of concern that may arise, providing multiple sites of access and points of entry to atheist groups and ideas and numerous ways of getting its messages across to a variety of audiences.

Our results not only echo this sentiment, but suggest a blending of these two views on the part of many individual nonbelievers, despite the fact that most responses concerning hostility in our study ranged from moderate to minor. Even majorities of those in our study who took an accommodationist stance did not opt out of circumstantially attacking, mocking, or ridiculing religion and religious beliefs. In the end, a more apt metaphor to accurately capture the situation may be one that does not describe "camps" but rather a sliding scale tempered by circumstance. 


\section{Bibliography}

Barna Group. Mar 2015. State of Atheism in America. Accessible at https://www.barna.org/ barna-update/culture/713-2015-state-of-atheism-in-america\#.Vw7wVzArKhc

Budd, Susan. 1977. Varieties of Unbelief: Atheists and Agnostics in English Society, 1850-1960. London: Heinemann.

Campbell, Colin. 1971. Toward a Sociology of Irreligion. London: Macmillan.

Cimino, Richard, and Christopher Smith. 2007. "Secular Humanism and Atheism Beyond Progressive Secularism.” Sociology of Religion 68: 407-424.

Cimino, Richard, and Christopher Smith. 2010. "The New Atheism and the Empowerment of American Freethinkers." In Religion and the New Atheism: A Critical Appraisal, edited by Amarnath Amarasingam, 139-156. Leiden: Brill.

Cimino, Richard, and Christopher Smith. 2011. "The New Atheism and the Formation of the Imagined Secularist Community." Journal of Media and Religion 10: 24-38.

Cotter, Christopher R. 2015. "Without God yet Without Nuance: A Qualitative Study of Atheism and Non-religion Among Scottish Students." In Atheist Identities-Spaces and Social Contexts, edited by Lori Beaman and Steven Tomlins, 171-194. London: Springer International Publishing.

Cragun, Ryan. 2014. "Who are the New Atheists?" In Atheist Identities: Spaces and Social Contexts, edited by Lori Beaman and Steven Tomlins, 195-211. Springer International Publishing.

Cragun, Ryan T., Barry Kosmin, Ariela Keysar, Joseph H. Hammer, and Michael Nielsen. 2012. "On the Receiving End: Discrimination Toward the Non-Religious in the United States." Journal of Contemporary Religion 27: 105-127.

Cragun, Ryan, and Lori L. Fazzino. 2014. "Splitters: Lessons from Monty Python for Nontheist/Freethought Organizations in the US." Presentation at the Annual Meeting of the Society for the Scientific Study of Religion in Indianapolis, IN.

Csaszar, David. 2010. "Standing on the Shoulders of Giants: The Voice of the 'New' Atheists." Over Dinner: The Laurier M.A. Journal of Religion and Culture, 1.

Gravetter, Frederick, and Larry Wallnau. 2008. Essentials of Statistics for the Behavioral Sciences (6th ed.). Belmont: Thomas Wadsworth.

Gould, Stephen Jay. 1999. Rocks of Ages: Science and Religion in the Fullness of Life. New York: Harmony Books.

Hackett, Conrad, Marcin Stonawski, Michaela Potančoková, Brian J. Grim, and Vegard Skirbekk. 2015. "The Future Size of Religiously Affiliated and Unaffiliated Populations." Demographic Research 32: 829-842.

Hassall, Christopher, and Ian Bushfield. 2014. "Increasing Diversity in Emerging Non-Religious Communities." Secularism and Nonreligion 3: 1-9.

Kettell, Steven. 2013. "Faithless: The Politics of New Atheism." Secularism and Nonreligion 2: $61-72$.

Kettell, Steven. 2014. "Divided We Stand: The Politics of the Atheist Movement in the United States." Journal of Contemporary Religion 29: 377-391.

Langston, Joseph, Joseph Hammer, and Ryan T. Cragun. 2015. "Atheism Looking In: On the Goals and Strategies of Organized Nonbelief." Science, Religion and Culture 2: $70-85$. LeDrew, Stephen. 2012. "The Evolution of Atheism: Scientific and Humanistic Approaches." History of the Human Sciences 25: 70-87. 
LeDrew, Stephen. 2014. “Atheists are Believers,” NSRN Blog, March 21, 2014, http://blog. nsrn.net/2014/03/21/atheists-are-believers/. Accessed on 31 May 2014.

LeDrew, Stephen. 2015. "Atheism Versus Humanism: Ideological Tensions and Identity Dynamics." In Atheist Identities-Spaces and Social Contexts, edited by Lori Beaman and Steven Tomlins, 53-68. London: Springer International Publishing.

McAnulla, Stuart. 2014. "Secular Fundamentalists: Characterising the New Atheist Approach to Secularism, Religion and Politics." British Politics 9: 124-145.

Miller, Ashley F. 2013. "The Non-Religious Patriarchy: Why Losing Religion HAS NOT Meant Losing White Male Dominance." Cross Currents 63: 211-226.

Putnam, R. D. (2001). Bowling Alone: The Collapse and Revival of American Community. Simon and Schuster.

Schnabel, Landon, Matthew Facciani, Ariel Sincoff-Yedid, and Lori L. Fazzino. Forthcoming. "Gender and Atheism: Paradoxes, Contradictions, and an Agenda for Future Research." Annual Review of the Sociology of Religion.

Schulzke, Marcus. 2013. "The Politics of New Atheism." Politics and Religion 6: 778-799.

Silver, Christopher F., Thomas J. Coleman III, Ralph W. Hood Jr, and Jenny M. Holcombe. 2014. "The Six Types of Nonbelief: A Qualitative and Quantitative Study of Type and Narrative." Mental Health, Religion \& Culture 17: 990-1001.

Smith, Christopher, and Richard Cimino. 2012. "Atheisms Unbound: The Role of the New Media in the Formation of a Secularist Identity." Secularism and Nonreligion 1: 17-31.

Smith, Jesse M. 2013. "Creating a Godless Community: The Collective Identity Work of Contemporary American Atheists." Journal for the Scientific Study of Religion 52: 80-99.

Stenger, Victor J. 2009. The New Atheism: Taking a Stand for Science and Reason. New York: Prometheus Books.

Stinespring, John, and Ryan Cragun. 2015. "Simple Markov Model for Estimating the Growth of Nonreligion in the United States.". Science, Religion and Culture 2: 96-103.

Stryker, Sheldon. 2000. "Identity Competition: Key to Differential Social Movement Participation?" In Self, Identity, and Social Movements, edited Sheldon Stryker, Timothy Joseph Owen, Robert W. White, 21-40. Minneapolis: University of Minnesota Press. 
